\title{
Evaluation of Different Hybrids for Growth and Tuberous Root Parameters of Flowers of Dahlia (Dahlia variabilis L.) Grown Under Allahabad Agroclimatic Condition
}

\author{
Dhanage Sony Baburao*, Lagamanna R. Kullur, G.H. Manavi and V.M. Prasad
}

Department of Horticulture, Sam Higginbottom University of Agriculture, Technology and Sciences, Allahabad (U.P.), India

*Corresponding author

\begin{tabular}{|c|c|}
\hline \multicolumn{2}{|r|}{ A B S T R A C T } \\
\hline & \multirow{6}{*}{$\begin{array}{l}\text { The present investigation entitled "Evaluation of different hybrids for growth, yield, and } \\
\text { quality of flowers of Dahlia (Dahlia variabilis L.) under Allahabad Agro-climatic } \\
\text { conditions" was undertaken at Department of Horticulture, during the year 2015-16. The } \\
\text { experiment was laid out in simple randomized block design with three replication and nine } \\
\text { treatments with a view to find out the overall evaluation of different hybrids of dahlia viz. } \\
\text { Sourave, Puesona, Baba borakanakeari, Sahani, Indira, Romia, Devdas, Mohini, } \\
\text { Bamakhefa, on the basis of different growth, yield and tuberous parameters. Maximum } \\
\text { plant height }(69.17 \mathrm{~cm}) \text { was recorded with hybrids Baba borakhenkeari. Maximum number } \\
\text { of leaves per plant (38.68) was observed in hybrid Indira. Maximum plant spread }(59.51 \\
\mathrm{cm} \text { ) was recorded in hybrid Puesona. Maximum number of primary branches per plant } \\
\text { (7.64) was found with hybrid Sourave. Maximum weight of single tuber }(152.80 \mathrm{~g} \text { ) was } \\
\text { found in hybrid Sourave. Maximum numbers of tuber per plant }(10.04) \text { was found in } \\
\text { hybrid Sourave. Maximum yield of tuber per plant ( } 279.39 \mathrm{~g} \text { ) were found in hybrid } \\
\text { Sourave. Maximum tuber yields (11.05 t/ha) was found in hybrid Sourave. Maximum } \\
\text { benefit cost ratios }(1: 3.57) \text { was found in hybrid Sourave. }\end{array}$} \\
\hline & \\
\hline $\begin{array}{l}\text { Varietal evaluation, } \\
\text { Dahlia, Sourave, } \\
\text { Sahani, Romia. }\end{array}$ & \\
\hline Article Info & \\
\hline $\begin{array}{l}\text { Accepted: } \\
\text { 15 October } 2017 \\
\text { Available Online: } \\
\text { 10 December } 2017\end{array}$ & \\
\hline & \\
\hline
\end{tabular}

\section{Introduction}

Dahlia (Dahlia variabilis L.) is tuberous rooted half hardy herbaceous perennials. Stems are mostly erect, branched, glabrous or scabrous, belonging to the Family Asteraceae having its origin in Mexico.

Dahlia was named in honor of the Swedish botanist Dr. Andereas Dahl, pupil of Linnaeus from where it was first introduced into Madrid (Spain) in 1789 and other European countries. Dahlia was introduced to India as early as 1857 under the auspices of the Agri
Horticultural society of India (formerly, Royal Agri - Horticultural society of India) Calcutta. Apart from cultivation in ground, Dahlia in pots is very popular in most parts of the country. The other notable contributions of this society are the development of late cutting method of dahlia preservation and plant breeding Dahlia originated in Mexico, which received its name by Cavanilles in the year 1791, to commemorate the work of a Swedish Botanist Dr. Andreas Dahl, a pupil of Linneaus (Dhane and Nimbalkar, 2002). 
The height of dahlia plants varies from 30 to $180 \mathrm{~cm}$ depending upon the cultivar. Dahlia flower consists of outer ray florets in which the male organs are modified in to a strap shaped petal, arranged round a central disk of bisexual florets.

Actually the ray florets in dahlia have all the flower colors, whereas the disk florets are generally yellow. In double flowered cultivars more of the male organs get converted in to ray petals with proportionate reduction in the number of dices.

\section{Materials and Methods}

The experiment was conducted with 9 varieties of dahlia viz. Sourave, Pue sona, Baba Borakhna keari, Sahani, Indira, Romia, Devdas, Mohini and Bama khefa, were sown randomized block design with 3 replication.

The experiment was conducted in the floriculture Research Farm, Department of Horticulture, Allahabad School of Agriculture Sam Higginbottom Institute of Agriculture, Technology and Sciences, Allahabad (Uttar Pradesh).

Observations were recorded on all characters viz. Height of plant, number of leaves per plant, plant spread, weight of single flower, number of tuber per plant, tuber yield per plant, tuber yield (t/ha). The data recorded during the course of investigation on growth components were subjected to two way classification analysis of variance (ANOVA), where the ' $F$ ' test was significant for comparison of the treatment means, CD values were worked out at $5 \%$ probability level.

\section{Results and Discussion}

Hybrids sourave showed maximum plant height $(69.56 \mathrm{~cm})$ followed by pue sona $(68.17 \mathrm{~cm})$ and romia $(66.01 \mathrm{~cm})$ whereas hybrid devdas showed the minimum plant height $(52.27 \mathrm{~cm})$ (Kamble and Reddy, 2004)

Sourave showed maximum number of leaves per plant (38.68) followed by pue sona (37.49) and sahana (31.19) whereas hybrid devdas showed the minimum number of leaves per plant (28.54).

Sourave showed maximum plant spread $(59.51 \mathrm{~cm})$ followed by pue sona $(58.99 \mathrm{~cm})$ and mohini $(51.92 \mathrm{~cm})$ whereas hybrid devdas showed the minimum plant spread (46.96 cm) (Kumar et al., 2009).

A maximum weight of single tuber $(152.80 \mathrm{~g})$ was found in hybrid sourave followed by pue sona (132.39 g) and bama khefa (111.67 g) whereas minimum weight of single tuber (59.31 g) was found in devdas (Singh and Mishra, 2005).

Maximum number of tuber per plant (10.04) was found in hybrid sourave followed by pue sona (8.60) and mohini (8.37). Whereas minimum number of tuber per plant (5.39) was found in devdas.

Maximum yield of tuber per plant (279.39 g) was found in hybrid sourave followed by pue sona (275.64 g) and romia (232.60 g) whereas minimum tuber yield of per plant $(156.60 \mathrm{~g})$ was found in devdas (Smith, 1971). Maximum tuber yield (11.50 t/ha) was found in hybrid sourave followed by pue sona (10.70 t/ha) and romia (10.42 t/ha). Whereas minimum tuber yield $(7.34 \mathrm{t} / \mathrm{ha})$ was found in devdas.

On the basis of present investigation it is concluded that, out of nine hybrids, sourave was to be most promising hybrids in terms of growth and tuberous root parameters of flowers of dahlia. As the study was undertaken only for one season, it needs further confirmation by conducting more trials (Table 1). 
Table.1 Evaluation of different hybrids for growth and tuberous root parameters of flowers of Dahlia (Dahlia variabilis L.) Grown Under Allahabad Agroclimatic Condition

\begin{tabular}{|c|c|c|c|c|c|c|c|c|}
\hline $\begin{array}{c}\text { Hybrid } \\
\text { Varieties }\end{array}$ & $\begin{array}{c}\text { Plant Height } \\
\text { (cm) }\end{array}$ & $\begin{array}{l}\text { Plant Spread } \\
(\mathrm{cm})\end{array}$ & $\begin{array}{c}\text { No. of leaves } \\
\text { per plant }\end{array}$ & $\begin{array}{c}\text { No. of } \\
\text { primary } \\
\text { branches per } \\
\text { plant }\end{array}$ & $\begin{array}{l}\text { Weight of } \\
\text { tuber }(\mathrm{g})\end{array}$ & $\begin{array}{l}\text { No, of tuber } \\
\text { per plant }\end{array}$ & $\begin{array}{c}\text { Tuber yield } \\
\text { per plant (g) }\end{array}$ & $\begin{array}{c}\text { Tuber yield } \\
\text { (t/ha) }\end{array}$ \\
\hline Sourave & 64.91 & 49.00 & 32.94 & 7.64 & 152.80 & 10.04 & 279.39 & 11.50 \\
\hline Puesona & 66.01 & 59.51 & 29.38 & 7.60 & 132.39 & 8.60 & 275.64 & 10.70 \\
\hline $\begin{array}{l}\text { Baba } \\
\text { Borakhnakeari }\end{array}$ & 69.56 & 46.96 & 37.49 & 5.31 & 83.0 & 5.64 & 192.37 & 5.82 \\
\hline Sahani & 56.89 & 49.24 & 31.19 & 8.68 & 61.40 & 7.0 & 162.08 & 7.56 \\
\hline Indira & 60.78 & 47.89 & 38.68 & 5.39 & 76.86 & 6.37 & 230.62 & 9.09 \\
\hline Romia & 68.17 & 49.78 & 29.71 & 6.62 & 72.2 & 7.64 & 232.60 & 10.42 \\
\hline Devdas & 57.28 & 47.91 & 34.13 & 4.51 & 59.31 & 5.39 & 156.60 & 7.34 \\
\hline Mohini & 52.27 & 51.92 & 28.54 & 5.78 & 104.08 & 8.37 & 164.80 & 8.26 \\
\hline Bamakhefa & 58.29 & 58.99 & 30.54 & 5.96 & 111.67 & 6.62 & 179.60 & 8.12 \\
\hline Mean & 61.65 & 51.45 & 32.58 & 6.38 & 94.97 & 7.24 & 208.36 & 79.62 \\
\hline F- test & $\mathbf{S}$ & $\mathbf{S}$ & $\mathbf{S}$ & $\mathbf{S}$ & $\mathbf{S}$ & $\mathbf{S}$ & $\mathbf{S}$ & $\mathbf{S}$ \\
\hline S.Ed \pm & 0.24 & 0.14 & 0.11 & 0.02 & 0.18 & 0.19 & 0.19 & 0.15 \\
\hline CD (5\%) & 0.51 & 0.30 & 0.24 & 0.04 & 0.23 & 0.41 & 0.39 & 0.32 \\
\hline
\end{tabular}




\section{References}

Dhane, A. V. and Nimbalkar, C. A., (2002). Growth and flowering performance of some dahlia varieties.

Kamble, B. S., Reddy, B. S., Patil R. T and Kulakarni, B. S., (2004), Evaluation of gladiolus cultivars for growth and yield. J. Orn. Hort., 7(3-4); 67-70.

Kumar, Lalan Mahawer, L.N. Shukla, Anil Kumar Kaushik, R.A Upadhyay, B. (2009). Performance of dahlia (Dahalia variabilis) cultivars for vegetative, floral and relative economic parameters under sub humid southern pains and Aravalli hills of Udaipur. Indi. J. Agri. Sci., 79(10): 816-20.

Singh, K.P. and Mishra R.L. (2005). Varietal evaluation of tuberose in and around Delhi condition. Prog. Hort., 37(1): 6771.

Smith, A. W., (1971), In; A gardener's dictionary of plant names. Cassel and compony Ltd, London. 390 p.

\section{How to cite this article:}

Dhanage Sony Baburao, Lagamanna R. Kullur, G.H. Manavi and Prasad, V.M. 2017. Evaluation of Different Hybrids for Growth and Tuberous Root Parameters of Flowers of Dahlia (Dahlia variabilis L.) Grown Under Allahabad Agroclimatic Condition. Int.J.Curr.Microbiol.App.Sci. 6(12): 2013-2016. doi: https://doi.org/10.20546/ijcmas.2017.612.231 